\title{
Efeito do retardamento da secagem na qualidade fisiológica de sementes armazenadas de azevém anual(1)
}

\author{
Luiz Eichelberger(2), Manoel de Souza Maia ${ }^{(3)}$, \\ Silmar Teichert Peske ${ }^{(3)}$ e Dario Munt de Moraes ${ }^{(4)}$
}

\begin{abstract}
Resumo - O objetivo deste trabalho foi avaliar os efeitos do retardamento da secagem e do armazenamento aberto na qualidade fisiológica de sementes de azevém anual (Lolium multiflorum Lam.), cultivar Comum-RS. Compararam-se períodos de retardamento da secagem $(0,2,4,6,8,12,18,24,36$ e 48 horas) e períodos de armazenamento ( 0,4 e 8 meses). Enquanto submetidas aos períodos de retardamento da secagem, $24 \mathrm{~kg}$ de sementes ficaram acondicionadas em 18 caixas de poliestireno. A secagem foi realizada sobre piso de concreto, à sombra, por 12 horas, sendo completada em estufa a $35^{\circ} \mathrm{C}$ com circulação forçada de ar. As sementes mantiveram o nível inicial de germinação durante os oito meses de armazenamento, mesmo com até 12 horas de retardamento da secagem; entretanto, com seis horas de retardamento, o vigor das sementes foi reduzido aos oito meses de armazenamento, mas se manteve praticamente inalterado aos quatro meses, com até 11 horas de retardamento. Sementes com germinação acima de $70 \%$ mantiveram este valor até oito meses de armazenamento, independentemente do período de retardamento da secagem.
\end{abstract}

Termos para indexação: Lolium multiflorum, armazenamento, germinação, vigor da semente.

\section{Drying delay effect on physiological quality of stored annual ryegrass seeds}

\begin{abstract}
The objective of this work was to study drying delay effect on physiological quality of annual ryegrass seeds (Lolium multiflorum Lam.), cultivar Comum-RS. Drying delay periods (0, 2, 4, 6 , $8,12,18,24,36$ and 48 hours) and storage periods ( 0,4 and 8 months) were compared. Drying delay was performed using 18 polystyrene boxes with $24 \mathrm{~kg}$ of seeds each. Following, seeds were placed on a shadowy concrete floor for 12 hours, followed by a drying period in a forced air oven. Seeds retained initial germination percentage after 8-month storage period with drying delay up to 12 hours. From 6-hour drying delay, seed vigor began to be reduced after 8-month storage period. Until 4-month storage period, seed vigor was maintained with up to 11-hour drying delay. Seeds with germination percentage above $70 \%$ retained those values until 8-month storage period unrelated to drying delay period.
\end{abstract}

Index terms: Lolium multiflorum, storage, germination, seed vigour.

\section{Introdução}

A longevidade das sementes durante o armazenamento aberto depende de sua qualidade

(1) Aceito para publicação em 11 de março de 2003.

Extraído da tese de doutorado apresentada pelo primeiro autor à Universidade Federal de Pelotas (UFPel), Faculdade de Agronomia Eliseu Maciel (Faem), Pelotas, RS.

(2) Embrapa-Centro Nacional de Pesquisa de Trigo, Caixa Postal 451, CEP 99001-970 Passo Fundo, RS. Bolsista da Capes. E-mail: luizei@ cnpt.embrapa.br

(3) UFPel, Dep. de Fitotecnia, Caixa Postal 354, CEP 96010-970 Pelotas, RS. E-mail: maiams@pro.via-rs.com.br, peske@ufpel.tche.br

(4) UFPel, Instituto de Biologia. E-mail: moraesdm@ufpel.tche.br inicial e da umidade relativa do ar e temperatura. No entanto, as principais condições que determinam a longevidade das sementes durante o armazenamento são a qualidade fisiológica e o grau de umidade iniciais (Roberts, 1986).

Segundo Harrington (1972), o grau ideal de umidade para o armazenamento aberto de sementes situa-se entre $10 \%$ e $13 \%$, e a longevidade é reduzida pela metade para cada ponto porcentual de elevação do grau de umidade no intervalo de 5\% a $14 \%$.

Sementes de azevém anual (Lolium multiflorum Lam.) são colhidas próximo da maturidade fisiológica, com grau de umidade entre $30 \%$ e $40 \%$ (Bazzigalupi, 1982). Pode-se, desse modo, além de antecipar-se à degrana das sementes, evitar a fase 
de deterioração no campo, permitindo, assim, obterse sementes com elevada qualidade e quantidade. Decorrente desse processo, é primordial para se obter elevada qualidade fisiológica a secagem das sementes até grau de umidade entre $12 \%$ e $13 \%$, o que permite seu armazenamento e posterior comercialização. Além do adequado processo de secagem, o tempo decorrido entre a colheita e o início de secagem também é importante (Gianluppi, 1988). Os dois fatores mais importantes envolvidos na capacidade de as sementes superarem esse período de espera de secagem são a espécie e o grau de umidade no momento da colheita (Andrigueto, 1975; Cerqueira, 1978; Valle, 1978).

Sob elevado grau de umidade, as sementes mantêm alta taxa de respiração que, em conjunto com a ação dos microrganismos, provoca elevação da temperatura (Martinelli, 1985). Inicialmente é prejudicado o vigor, diminuindo a capacidade de armazenamento e, posteriormente, a germinação, até a completa deterioração. A velocidade da deterioração é tanto maior quanto mais alto for o grau de umidade das sementes e esse processo é tanto mais drástico quanto maior for o tempo do retardamento da secagem.

O objetivo deste trabalho foi estudar os efeitos do retardamento da secagem e do armazenamento aberto na qualidade fisiológica de sementes de azevém anual.

\section{Material e Métodos}

O trabalho foi realizado no Departamento de Fitotecnia da Faculdade de Agronomia Eliseu Maciel, Universidade Federal de Pelotas, Pelotas, RS, de abril de 1997 a dezembro de 1998.

As sementes de azevém foram colhidas quando apresentaram grau de umidade de $35 \%$. Foram comparados os períodos de retardamento de secagem de $0,2,4,6,8,12$, $18,24,36$ e 48 horas após a colheita e períodos de armazenamento de 0,4 e 8 meses.

$\mathrm{Na}$ colheita, realizada com colhedora automotriz, foram obtidos aproximadamente $500 \mathrm{~kg}$ de sementes com $85,1 \%$ de pureza, sendo submetidas aos períodos de retardamento da secagem em 18 caixas de poliestireno (40x50x80 cm) contendo, cada uma, $24 \mathrm{~kg}$ de sementes. As caixas permaneceram abertas na parte superior. A temperatura das sementes foi medida a cada hora, nas primeiras seis horas, e ao término de cada período de retar- damento, com termômetro digital cujo sensor foi colocado no centro da caixa por ocasião do enchimento. Após cada período de retardamento, uma camada superior de $20 \mathrm{~cm}$ de sementes foi eliminada. O restante das sementes foi homogeneizado e $5 \mathrm{~kg}$ foram separados. Nas primeiras 12 horas, a secagem foi realizada à sombra, sobre piso de concreto. A secagem continuou em estufa a $35^{\circ} \mathrm{C}$ com ventilação forçada até as sementes atingirem grau de umidade ao redor de $13 \%$. A seguir, as sementes foram limpas em máquina de ar e peneiras, ficando com 90,4\% de pureza, e amostradas para os testes de laboratório. Dispostas de modo aleatório, as sementes foram armazenadas na unidade de beneficiamento, em pilha única, sobre lastro de madeira a $0,50 \mathrm{~m}$ do piso. Aos quatro e oito meses foram novamente amostradas. A temperatura e a umidade relativa do ar foram registradas em termoigrógrafo.

Após cada período de retardamento da secagem e de armazenamento, foi determinado o grau de umidade em duas subamostras de $1,0 \mathrm{~g}$ de sementes em estufa (105 $\pm 3^{\circ} \mathrm{C} / 24$ horas) (Brasil, 1992), sendo os resultados expressos em porcentagem base úmida.

As sementes de cada tratamento foram submetidas aos testes de germinação e de envelhecimento acelerado e à determinação do peso de mil sementes.

No teste de germinação, para a superação da dormência, as sementes foram submetidas ao pré-resfriamento a $5^{\circ} \mathrm{C}$ por sete dias, em caixas de plástico tipo gerbox sobre papel umedecido com volume de água destilada equivalente a 2,5 vezes o peso do substrato. Em seguida, foram colocadas em germinador duas subamostras de 100 sementes, a $20^{\circ} \mathrm{C}$ constante e luz. Foi realizada uma contagem aos cinco dias e outra aos 14 dias após o início do teste de germinação. Ao final do teste, as sementes não germinadas foram submetidas ao teste de tetrazólio para avaliação de dormência, após corte longitudinal através do embrião até três quartos do endosperma. A concentração da solução de 2, 3, 5-trifenil cloreto de tetrazólio foi de $0,5 \%$ e o tempo de coloração de cinco horas, a $30^{\circ} \mathrm{C}$ (Brasil, 1992).

$\mathrm{O}$ teste de envelhecimento acelerado foi realizado segundo Delouche \& Baskin (1973), colocando-se 1,0 g de sementes sobre tela em caixas de plástico tipo gerbox, com $40 \mathrm{~mL}$ de água destilada no fundo, e mantidas em câmara de incubação BOD a $40^{\circ} \mathrm{C}$ por 72 horas. Ao final desse período, as sementes apresentaram grau de umidade de $39 \%$, que é recomendado por Hampton \& Tekrony (1995); em seguida, foi realizado o teste de germinação, e a avaliação das plântulas feita aos cinco e aos 14 dias, de acordo com Brasil (1992).

A determinação do peso de mil sementes (PMS) foi realizada em quatro repetições de 100 sementes, e os resultados expressos em gramas.

O delineamento experimental foi o inteiramente casualizado em parcelas subdivididas, sendo atribuídos às 
parcelas os níveis do fator retardamento da secagem, e às subparcelas os níveis do fator armazenamento, com duas repetições. Para os dois fatores foram feitas análises de regressão polinomial. As porcentagens de germinação e de vigor (primeira contagem e envelhecimento acelerado) foram transformadas para arco seno da raiz quadrada da $\% / 100$. Na análise estatística dos dados utilizou-se o programa SANEST.

\section{Resultados e Discussão}

O retardamento da secagem e o armazenamento influenciaram todas as variáveis analisadas. Da mesma forma, a interação entre os dois fatores foi significativa, com exceção do peso de mil sementes (Tabela 1).

O grau de umidade na colheita das sementes foi de $34,9 \%$, mantendo-se aproximadamente constante durante os períodos de retardamento da secagem. A temperatura das sementes na colheita foi de $28,9^{\circ} \mathrm{C}$. Com o retardamento da secagem, a temperatura elevou-se rapidamente nas primeiras 12 horas, atingindo $43,1^{\circ} \mathrm{C}$ (Figura 1). Entre 12 horas e 24 horas, metade do período de retardamento, a temperatura aumentou mais lentamente, atingindo $50,4^{\circ} \mathrm{C}$. Em sementes com elevado grau de umidade, a atividade respiratória e a multiplicação de microrganismos, principalmente bactérias e fungos, inicia o processo fermentativo aeróbico resultando em elevação de temperatura pelo acúmulo da energia calórica liberada pelas reações de oxidação desse processo (Wardynski et al., 1993).

A partir de 24 horas de retardamento, a temperatura das sementes praticamente se estabilizou, com pequeno aumento até 38 horas $\left(53,2^{\circ} \mathrm{C}\right)$, reduzindose, posteriormente, até 48 horas $\left(51,5^{\circ} \mathrm{C}\right)$. A esta- bilização da temperatura nos estágios mais avançados de retardamento pode ter sido causada pela queda da taxa de respiração decorrente da morte das sementes e da maioria dos microrganismos, que tem a atividade reduzida sob elevada temperatura. Fungos de armazenamento, como Aspergillus, tem atividade reduzida em temperatura acima de $35^{\circ} \mathrm{C}$ e temperatura máxima entre $38^{\circ} \mathrm{C}$ e $55^{\circ} \mathrm{C}$, dependendo da espécie; em relação a Penicillium, esses limites são mais baixos, ou seja, ótima ao redor de $25^{\circ} \mathrm{C}$ e máxima de $35^{\circ} \mathrm{C}$ (Ayerst, 1969).

Nos primeiros quatro meses de armazenamento, $\mathrm{O}$ grau de umidade das sementes se manteve praticamente constante, o que coincidiu com os meses de verão, mais quentes e com umidade relativa do ar mais baixa $(74,2 \%$ em dez./97, 75,6\% em jan./98, 77,9\% em fev./98 e 77,5\% em mar./98). Nos meses de abril, maio, junho e julho, com umidade relativa do ar mais elevada $(82,2 \%, 83,1 \%, 84,5 \%$ e $87,4 \%$, respectivamente), a umidade das sementes teve aumento de $0,76 \%$. Em média, a umidade das sementes oscilou entre 13,5\% e 15,3\%. Segundo Delouche (1968), sementes de azevém anual entram em equilíbrio com umidade relativa do ar de $75 \%, 80 \%$ e $85 \%$ quando o grau de umidade atingir $14,1 \%, 15,7 \%$ e $16,3 \%$, respectivamente.

Quando a secagem não foi retardada, a germinação aumentou $5 \%$ nos primeiros quatro meses de armazenamento, possivelmente em razão da superação de dormência, retornando ao valor inicial ao fim de oito meses de armazenamento (Figura 2).

Com duas e quatro horas de retardamento da secagem, o efeito do armazenamento sobre a germinação da semente não foi significativo. Nesse período,

Tabela 1. Níveis de significância, coeficientes de variação (CV) e interações entre períodos de retardamento da secagem e períodos de armazenamento do grau de umidade, germinação, primeira contagem da germinação (PCG), envelhecimento acelerado (EA) e peso de mil sementes (PMS) de sementes de azevém anual submetidas a retardamento de secagem (R) e armazenamento (A).

\begin{tabular}{|c|c|c|c|c|c|}
\hline \multirow[t]{3}{*}{ Variáveis } & \multicolumn{4}{|c|}{ Causas da variação } & \multirow{3}{*}{$\begin{array}{c}\text { Interação } \\
(\mathrm{R} \times \mathrm{A})\end{array}$} \\
\hline & \multicolumn{2}{|c|}{ Retardamento da secagem } & \multicolumn{2}{|c|}{ Armazenamento } & \\
\hline & Significância & $\mathrm{CV}(\%)$ & Significância & $\mathrm{CV}(\%)$ & \\
\hline Grau de umidade & - & - & * & 3,41 & - \\
\hline Germinação & $* *$ & 2,89 & $* *$ & 3,73 & $* *$ \\
\hline PCG & $* *$ & 2,89 & $*$ & 4,01 & $* *$ \\
\hline EA & $* *$ & 2,62 & $*$ & 3,65 & $* *$ \\
\hline PMS & $* *$ & 0,60 & $* *$ & 1,12 & $\mathrm{~ns}$ \\
\hline
\end{tabular}

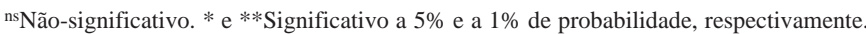


a temperatura das sementes ainda se manteve relativamente baixa. Com seis e oito horas de retardamento da secagem, verificou-se uma retomada da germinação quando as sementes foram armazenadas por quatro meses. Após quatro meses, a queda de germinação representou o efeito do armazenamento, o que também foi verificado por Maia (1995). $\mathrm{O}$ aumento da taxa respiratória pode ter aumentado a concentração de $\mathrm{CO}_{2}$ no depósito das sementes, o que pode ter induzido dormência secundária (Popinigis, 1985; Bewley \& Black, 1994).

O efeito do retardamento da secagem na germinação das sementes ajustou-se a modelos cúbicos. A característica dessa resposta, muito semelhante nos três períodos de armazenamento, identifica processo de ação térmica na superação de dormência nas primeiras quatro horas de retardamento da secagem, quando a temperatura das sementes atingiu $35,7^{\circ} \mathrm{C}$, o que não causa danos à qualidade das sementes, conforme He et al. (1994).

Após 12 horas de retardamento da secagem, iniciou-se acentuada redução da germinação, porém se manteve acima do padrão mínimo de $70 \%$ vigente para o Estado do Rio Grande do Sul (Rio Grande do Sul, 1998) até 18 horas, independentemente do período de armazenamento. Para tempos de retardamento da secagem acima de 18 horas, a germinação das sementes se apresentou abaixo de $70 \%$, atingindo
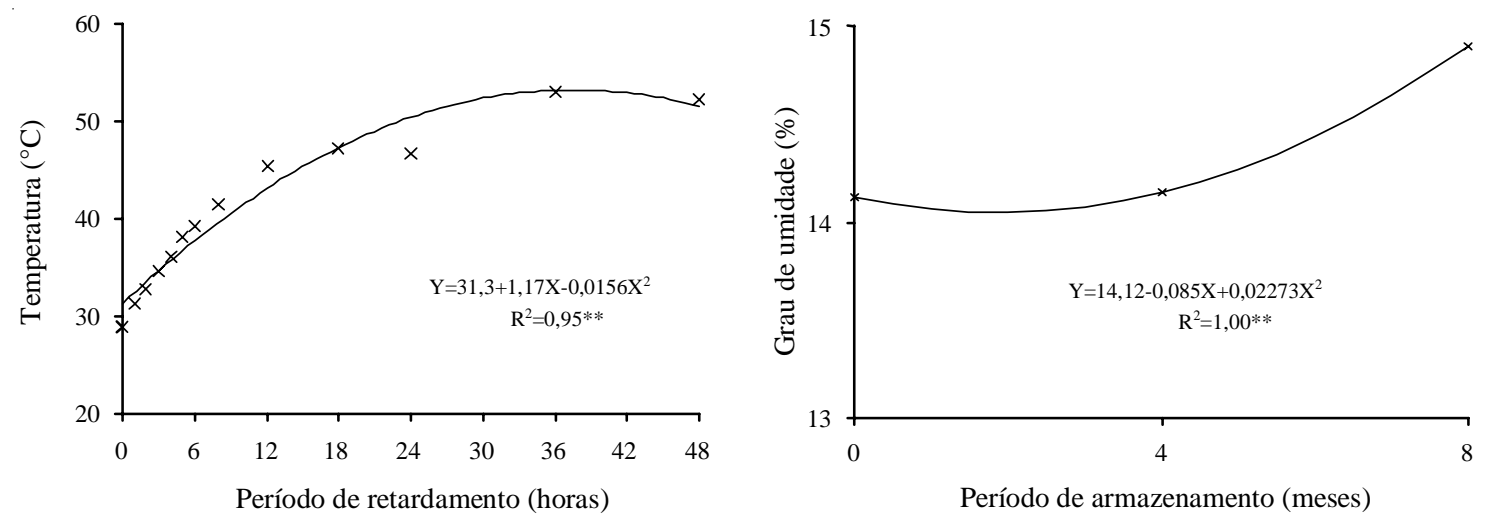

Figura 1. Temperatura das sementes de azevém anual durante o retardamento da secagem e grau de umidade durante o armazenamento.
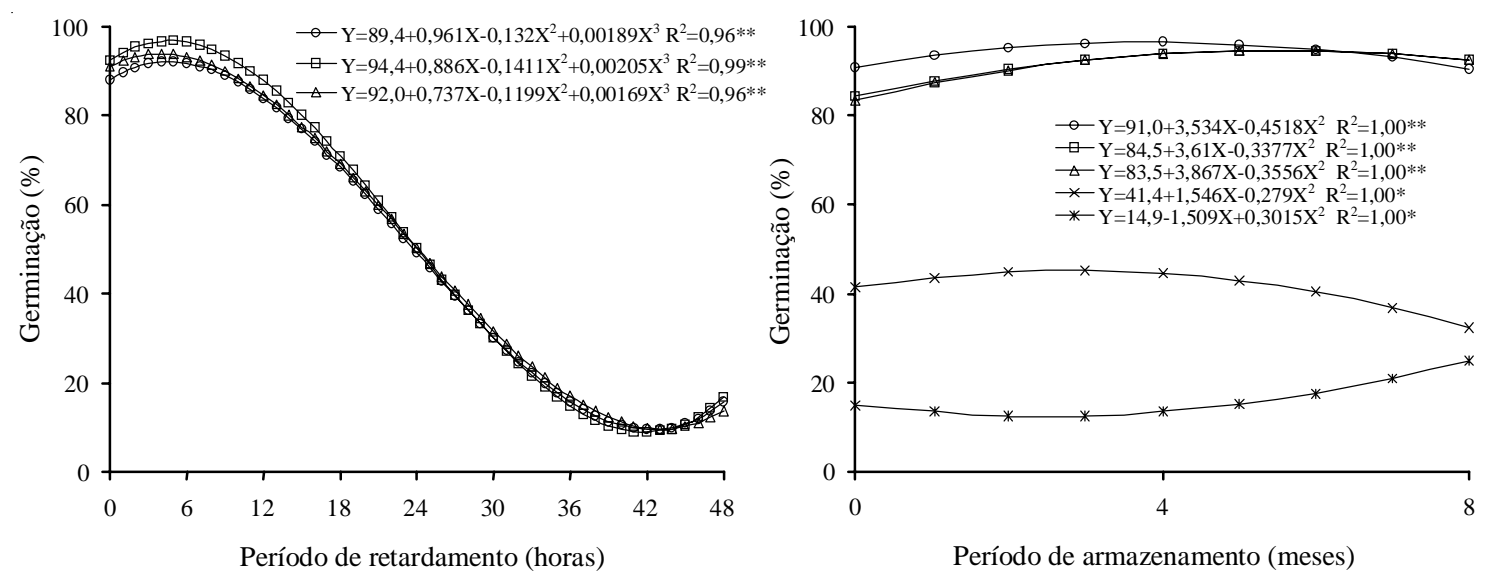

Figura 2. Germinação de sementes de azevém anual submetidas a retardamento da secagem por $0(\mathrm{O}), 6(\square) 8(\Delta)$, $24(\times)$ e $36(*)$ horas e armazenadas por $0(\mathrm{O}), 4(\square)$ e $8(\Delta)$ meses. 
valores entre $10 \%$ e $14 \%$ com 48 horas de retardamento da secagem.

De modo geral, o efeito do armazenamento pode ser interpretado sob três aspectos. Primeiro, quando se verificou a presença de dormência primária, resposta predominante nos períodos menores de retardamento da secagem. O segundo aspecto está relacionado com a indução de dormência secundária pelo aumento de concentração de $\mathrm{CO}_{2}$ durante o retardamento da secagem, a partir da respiração estimulada pelo elevado grau de umidade e pela elevação da temperatura das sementes. Em azevém anual analisado logo após a colheita, Eichelberger et al. (2001) observaram que a superação de dormência pelo método de pré-resfriamento (Brasil, 1992), pode não ser totalmente eficaz. Segundo Popinigis (1985) e Bewley \& Black (1994), a dormência das sementes desaparece lentamente durante o armazenamento. O terceiro aspecto está associado ao dano provocado pelo armazenamento que se manifestou pela redução da germinação a partir de quatro meses de armazenamento.

$\mathrm{O}$ vigor das sementes determinado pela primeira contagem da germinação teve comportamento semelhante ao da germinação (Figura 3). Entretanto, pelo teste de envelhecimento acelerado, os resultados mostraram que, utilizando-se equações de regressão, o vigor das sementes manteve-se inalterado até 11 horas de retardamento da secagem com quatro meses de armazenamento, e por seis horas quan-

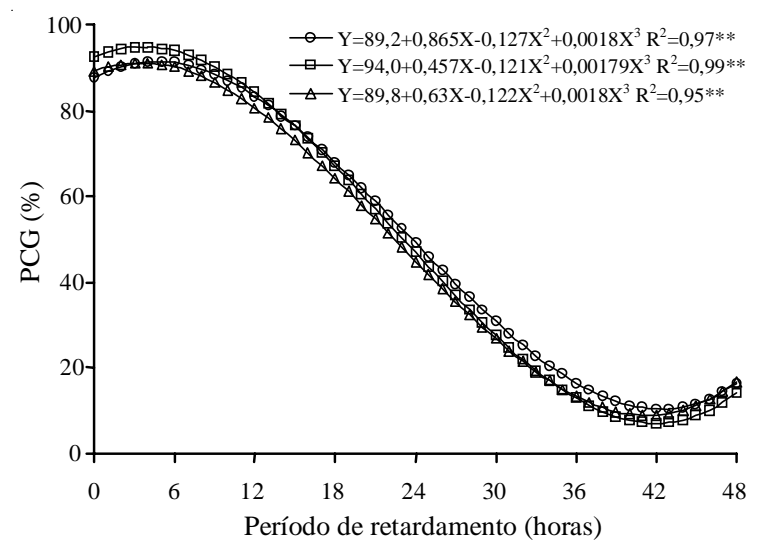

do armazenadas por oito meses (Figura 4). A antecipação do início da queda de vigor nas sementes armazenadas por oito meses indica o efeito latente do retardamento, pois o efeito de possíveis danos provocados pela elevação da temperatura durante o retardamento foi antecipado.

A semelhança dos resultados de germinação e de vigor mostra que pode ter ocorrido envigoramento das sementes por causa da elevação da umidade das sementes durante o teste de envelhecimento, antecipando eventos que ocorrem durante o processo germinativo (Burgass \& Powell, 1984; Pijlen et al., 1996). A elevada temperatura do teste pode, também, ter causado superação de dormência residual das sementes (Popinigis, 1985; Bewley \& Black, 1994).

$\mathrm{O}$ efeito do armazenamento, quando a secagem foi retardada por 18 horas, período em que a germinação das sementes se aproxima de $70 \%$, foi significativo (Figura 4), apresentando valores de 79,5\%, $72,5 \%$ e $69,5 \%$ nos períodos de zero, quatro e oito meses de armazenamento, respectivamente. Outros efeitos significativos ocorreram quando o vigor das sementes foi elevado (2, 6 e 12 horas de retardamento) ou quando os valores foram baixos (36 horas). Com $0,4,8,24$ e 48 horas, o efeito do armazenamento sobre o vigor não foi significativo.

O efeito do retardamento da secagem sobre o peso de mil sementes, independentemente do período de armazenamento, ajustou-se ao modelo quadrático (Figura 5). A redução do peso de mil sementes foi

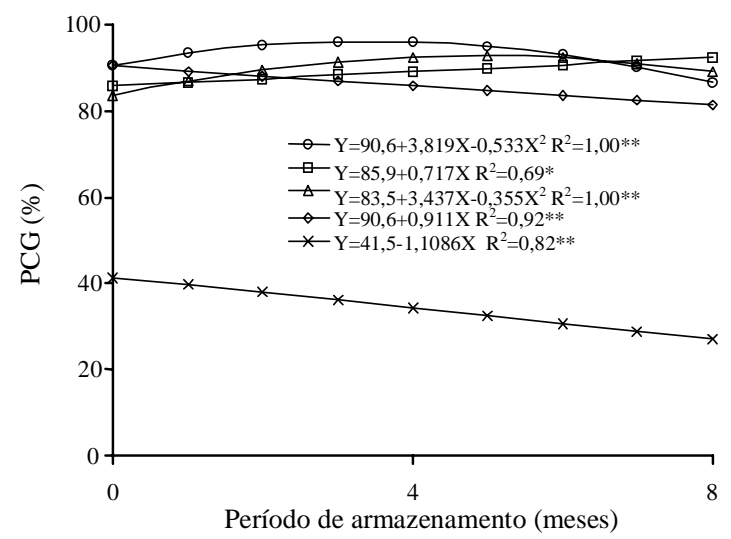

Figura 3. Primeira contagem (PCG) de sementes de azevém anual submetidas a retardamento da secagem por $0(\mathrm{O})$, $6(\square), 8(\Delta), 12(\diamond)$ e $24(\times)$ horas e armazenadas por $0(\mathrm{O}), 4(\square)$ e $8(\Delta)$ meses. 
pequena nas primeiras horas, coincidindo com o período de qualidade fisiológica mais elevada; entretanto, com o retardamento da secagem por períodos mais longos, a redução foi mais acentuada, possivelmente pelo consumo de reservas em razão do aumento da atividade respiratória das sementes, causada pelo elevado grau de umidade e pela elevada temperatura.

Sem retardamento da secagem, o peso de mil sementes foi de 2,41 g logo após a colheita, diminuin- do para 2,24 g e 2,26 g após quatro e oito meses de armazenamento, respectivamente. $\mathrm{O}$ peso de mil sementes sofreu acentuada redução nos primeiros quatro meses de armazenamento, nos quais a temperatura ambiental foi mais elevada (média de $24^{\circ} \mathrm{C}$ ), o que talvez aumentou a atividade respiratória das sementes, e se manteve constante dos quatro aos oito meses de armazenamento, com temperaturas mais baixas (média de $15,5^{\circ} \mathrm{C}$ ). Essa tendência se manteve independentemente do tempo de retardamento.
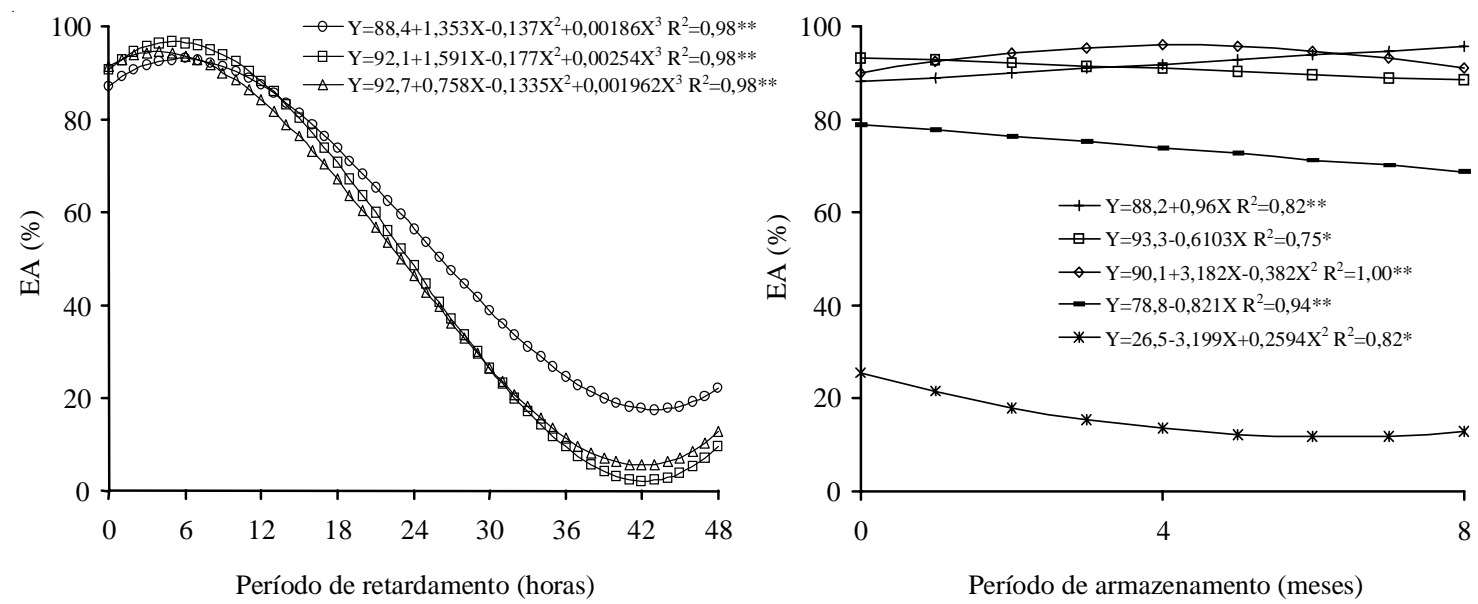

Figura 4. Envelhecimento acelerado (EA) de sementes de azevém anual submetidas a retardamento da secagem por $2(+), 6(\square), 12(\diamond), 18(-)$ e $36(*)$ horas e armazenadas por $0(O), 4(\square)$ e $8(\Delta)$ meses.
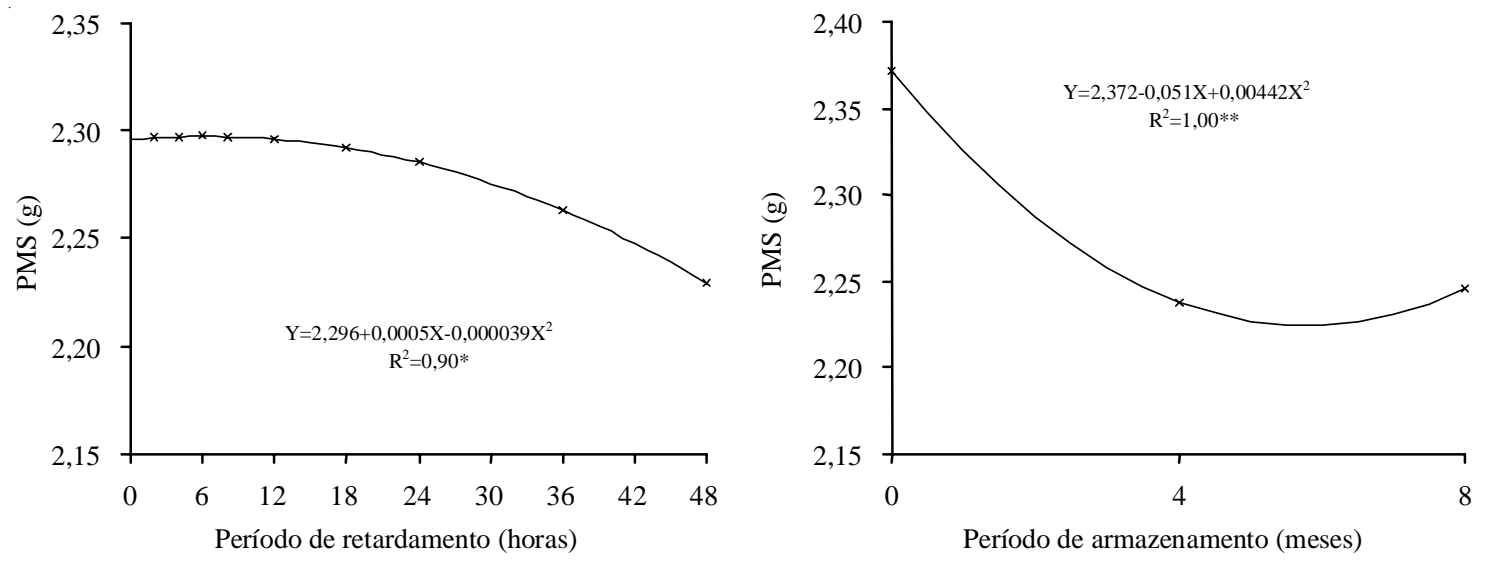

Figura 5. Peso de mil sementes (PMS) de sementes de azevém anual submetidas a retardamento da secagem e armazenamento. 


\section{Conclusões}

1. O retardamento da secagem de sementes de azevém anual colhidas com elevada umidade eleva rapidamente a temperatura das sementes.

2. A secagem de sementes de azevém anual pode ser retardada por até 12 horas e mesmo assim as sementes conservam a germinação durante armazenamento de oito meses.

3. Em períodos de armazenamento mais longos, o vigor é reduzido nas sementes cuja secagem foi retardada por mais de seis horas.

4. Em curtos períodos de armazenamento, o vigor não é afetado em sementes cuja secagem foi retardada por até 11 horas.

5. Sementes com germinação acima de $70 \%$, independentemente do período de retardamento da secagem, mantêm essa capacidade de germinação por oito meses de armazenamento.

\section{Referências}

ANDRIGUETO, J. P. Efeitos do retardamento de secagem de sementes de trigo (Triticum aestivum) sobre sua qualidade fisiológica. 1975. 73 f. Dissertação (Mestrado em Agronomia) - Universidade Federal de Pelotas, Pelotas, 1975.

AYERST, G. J. The effects of moisture and temperature on growth and spore germination in some fungi. Journal of Stored Products Research, Oxford, v. 5, n. 3, p. 127 $141,1969$.

BAZZIGALUPI, O. Efeito da época de colheita sobre o rendimento e a qualidade de sementes de azevém anual Lolium multiflorum Lam. cv. Comum-RS. 1982. 75 f. Dissertação (Mestrado em Agronomia) - Universidade Federal de Pelotas, Pelotas, 1982.

BEWLEY, J. D.; BLACK, M. Seeds: physiology of development and germination. New York: Plenum, 1994. $445 \mathrm{p}$.

BRASIL. Ministério da Agricultura e Reforma Agrária. Regras para análise de sementes. Brasília: Secretaria Nacional de Defesa Agropecuária, 1992. 365 p.

BURGASS, R. W.; POWELL, A. A. Evidence for repair process in the invigoration of seeds by hydration. Annals of Botany, London, v. 53, n. 5, p. 753-757, 1984.

CERQUEIRA, W. P. Efeitos do retardamento de secagem de sementes de soja (Glycine max (L.) Merril) sobre sua qualidade fisiológica. 1978. 80 f. Dissertação (Mestrado em Agronomia) - Universidade Federal de Pelotas, Pelotas, 1978.

DELOUCHE, J. C. Precepts for seed storage. In: SHORT course for seedsmen. State College: Mississippi State University, 1968. p. 81-119.

DELOUCHE, J. C.; BASKIN, C. C. Accelerated aging techniques for predicting the relative storability of seed lots. Seed Science and Technology, Zurich, v. 1, n. 2, p. $427-452,1973$.

EICHELBERGER, L.; MAIA, M. S.; CAMACHO, J. C. B. Períodos de pré-esfriamento na superação da dormência de sementes de azevém-anual (Lolium multiflorum Lam.). Revista Brasileira de Sementes, Brasília, v. 23, n. 1, p. 212-218, 2001.

GIANLUPPI, V. Influência do peso de $\mathbf{1 0 0 0}$ sementes na qualidade fisiológica de azevém anual (Lolium multiflorum). 1988. 44 f. Dissertação (Mestrado em Agronomia) - Universidade Federal de Pelotas, Pelotas, 1988.

HAMPTON, J. G.; TEKRONY, D. M. Handbook of vigour test methods. $3^{\text {rd }}$ ed. Zurich: International Seed Testing Association, 1995. $117 \mathrm{p}$.

HARRINGTON, J. F. Seed storage and longevity. In: KOZLOWSKI, T. T. Seed biology. New York: Academic, 1972. v. 3, p. 145-245.

HE, Y. L.; HU, X. H.; SHAO, Y.; SHI, Y. H. Influence of different dry strength on seed vigor of Lolium multiflorum Lam. Journal of Shanghai Agricultural College, Shanghai, v. 12, n. 4, p. 266-270, 1994.

MAIA, M. S. Secagem de sementes de azevém anual (Lolium multiflorum) com ar ambiente forçado. 1995. 108 f. Tese (Doutorado em Agronomia) - Universidade Federal de Pelotas, Pelotas, 1995.

MARTINELLI, R. R. Efeitos do retardamento na secagem da semente de sorgo sacarino sobre sua qualidade fisiológica. 1985. $60 \mathrm{f}$. Dissertação (Mestrado em Agronomia) - Universidade Federal de Pelotas, Pelotas, 1985.

PIJLEN, J. G.; GROOT, S. P. C.; KRAAK, H. L.; BERGERVOET, J. H. W.; BINO, R. J. Effects of prestorage hydration treatments on germination performance, moisture content, DNA synthesis and controlled deterioration tolerance of tomato (Lycopersicon esculentum Mill.) seeds. Seed Science Research, Oxon, v. 6, n. 2, p. 57-63, 1996. 
POPINIGIS, F. Fisiologia da semente. 2. ed. Brasília: [s.n.], 1985. 289 p.

RIO GRANDE DO SUL. Secretaria da Agricultura e Abastecimento. Departamento de Produção Vegetal. Comissão Estadual de Sementes e Mudas. Normas e padrões de produção de sementes para o Estado do Rio Grande do Sul. 2. ed. Porto Alegre, 1998. 156 p.

ROBERTS, E. H. Quantifying seed deterioration. In: McDONALD JUNIOR, M. B.; NELSON, C. J. (Ed.).

Physiology of seed deterioration. Madison: American Society of Agronomy/Crop Science Society of America/
Soil Science Society of America, 1986. p. 101-123. (Special Publication, 11).

VALLE, I. C. Efeitos do retardamento de secagem de sementes de arroz Bluebelle (Oryza sativa L.) sobre sua qualidade fisiológica. 1978. 56 f. Dissertação (Mestrado em Agronomia) - Universidade Federal de Pelotas, Pelotas, 1978.

WARDYNSKI, F. A.; RUST, S. R.; YOKOYAMA, M. T. Effect of microbial inoculation of high-moisture corn on fermentation characteristics, aerobic stability, and cattle performance. Journal of Animal Science, Champaign, v. 71, n. 8 , p. $2246-2252,1993$. 